\title{
Bradykinin Receptor B1 Measurement
}

National Cancer Institute

\section{Source}

National Cancer Institute. Bradykinin Receptor B1 Measurement. NCI Thesaurus. Code C139099.

The determination of the amount of bradykinin receptor B1 present in a sample. 